\title{
Co-created visual narratives and inclusive place branding: a socially responsible approach to residents' participation and engagement
}

\author{
Cátia Rebelo $^{1}\left[{ }^{1} \cdot\right.$ Abid Mehmood $^{1} \cdot$ Terry Marsden $^{1}$
}

Received: 2 February 2019 / Accepted: 31 October 2019 / Published online: 21 November 2019

(c) The Author(s) 2019

\begin{abstract}
This paper discusses the importance of co-created visual narratives in developing participatory and inclusive place branding. We refer to the need for a socially responsible approach when considering place branding policies and practices. For this purpose, we develop and empirically apply a novel framework with four interconnected phases comprising place-based contextualization, re-appreciation, re-positioning, and consolidation of residents' perceptions, experiences and aspirations to develop and initiate inclusive place branding processes. Using participatory research and collaborative visual methods, we worked with a group of residents in Carvalhal de Vermilhas, Portugal. This work stimulated the co-development of collective agency to consider narratives, values and identities to be articulated for creating and promoting more inclusive representation of place in a (hypothetical) branding exercise. The framework application as well as its challenges and limitations, particularly in co-creation processes, were critically deliberated at all phases. Collaborative visual techniques from our analysis emerge as valuable participatory tools for researchers towards improving residents' participation in place branding, and therefore contributing towards a more inclusive form of this practice. However, we are also aware of the perils associated with communities' opening up their pristine heritage to touristic ventures, and hence suggest considering the importance of sustainable place-shaping in all branding decisions.
\end{abstract}

Keywords Inclusive place branding $\cdot$ Sustainable place-shaping $\cdot$ Collaborative visual methods $\cdot$ Participatory action research · Citizen engagement $\cdot$ Transformative agency

\section{Introduction}

Place branding practices aim to support policies in the improvement of place image(s) and thus benefit residents, businesses and visitors (Boisen et al. 2017). Nevertheless, mainstream place branding practices often appear to prioritize economic interests over social wellbeing. Consequently,

Handled by Erik Mathijs, Katholieke Universiteit Leuven, Belgium.

Cátia Rebelo

cerqueirarebeloc@cardiff.ac.uk

Abid Mehmood

mehmooda1@cardiff.ac.uk

Terry Marsden

marsdenTK@ cardiff.ac.uk

1 Sustainable Places Research Institute, Cardiff University, 33 Park Place, CF10 3BA Cardiff, UK the needs of residents are overlooked. Such practices have resulted in counter-branding protests by people as well as fierce criticisms by many scholars (see Lichrou et al. 2008; Johansson 2012). Nevertheless, place branding studies often fail to provide clear frameworks for inclusiveness such as how to successfully involve, engage, and empower local actors, particularly the underprivileged, in the branding process (Vanolo 2017). In recent times, a stakeholder-oriented body of the literature has attained traction, which challenges the mainstream notions by arguing for place branding to be seen as a participatory and collaborative process that helps (re)define the meaning of the place for its various users and stakeholders (Braun et al. 2013; Kavaratzis 2012; Kavaratzis and Kalandides 2015; Klijn et al. 2012; Zenker and Erfgen 2014). These views are pushing the boundaries of place branding as a socially responsible and inclusive approach. Yet, a gap continues to exist between conceptualising and applying a clear framework for local actors' engagement in participatory and inclusive place branding. Lichrou et al. 
(2017) in this respect call for further exploratory studies to appraise new concepts, theories, and methodologies which can assist with a better understanding of inclusive place branding.

To fill the methodological and conceptual divide, we propose a novel framework informed by empirical research, which links critical views of place branding with interdisciplinary perspectives in sustainable place-shaping. We argue that integrating place-shaping processes with the roles that residents play in place branding can help with actively engaging and empowering residents as agents of transformative change in the course of branding their places, mainly based on local values and meanings. In this respect, the following research questions are of particular importance:

1. How could an approach based on sustainable placeshaping processes help enhance residents' support and engagement in inclusive place branding?

2. What role could the collaborative visual narratives play in socially responsible and inclusive forms of place branding?

We address these questions from two perspectives, conceptual and methodological: conceptually, we look at interdisciplinary conceptualizations of place branding and sustainable place-shaping. This allows for a new framework that is grounded in the inclusiveness of place and place meanings, especially when encouraging community support, engagement and empowerment. Methodologically, we argue for a collaborative and innovative visual methodology. This includes co-creation of visual narratives, in the form of a video documentary, as a means to engage and empower research participants, whilst empirically applying the proposed conceptual framework. For this purpose, a remote community in rural Portugal was selected as a case study. The aim was not just to present and analyse what for the participants may constitute the place brand and their identity (expressed in the documentary), but to explore and reflect on how the new framework, aligned with an action research approach, assisted the development of a potential participatory and inclusive place brand which successfully engaged and included residents in the process.

The next section briefly explores what is understood as sustainable place-shaping. Section "From mainstream place branding to inclusive place-based approaches" provides a short overview of conceptual discussions in place branding literature. Section "Inclusive place branding: a framework to enhance residents' participation via sustainable placeshaping" presents the new framework based on residents' involvement in place branding via place-shaping processes. Section "Methodology-collaborative visual narratives" presents research methodology and introduces the case study as well as data collection. The results are analysed in
Sect. "Results: application and analysis of the conceptual framework", followed by critical discussion in Sect. "Discussion". The paper concludes with critical reflections on visualization of place and future pathways.

\section{Understanding sustainable place-shaping}

Place-shaping is often referred to as a collective and deliberative process of re-imagining socio-spatial relations by building connections between the past and the future (Shucksmith 2010). However, this future-oriented definition has also been interpreted as a means of economic growth, place management, localism, and even gentrification (Allen and Crookes 2009). Hence, there is a need for 'sustainable place-shaping' which aims to transform the relations between social actors and their place. It does not just connect people to place but also acknowledges their potential transformative agency to shape their place by means of their own values, ideas and needs (Horlings and Roep 2015).

Three interconnected pathways for place-shaping practices have been identified in the literature (Horlings and Roep 2015): “(1) re-appreciation, which includes perceptions, meanings and values attached to place, processes of sense-making and how actors take the lead in appreciating places; (2) re-grounding, rooted in (agro-) ecological and cultural place-based assets and resources, influenced by wider communities, cultural notions, values, assets, technology and historical patterns; (3) re-positioning, both of alternative, diverse or 'hidden' economies (Gibson-Graham 2008) and of ways of value-adding, or altering politicaleconomic relations shaped by globalization." (Horlings 2017:134). Such processes require participation, empowerment and capacity building of the actors involved (Horlings 2016).

These pathways provide an exploratory device (explained in Sect. "Inclusive place branding: a framework to enhance residents' participation via sustainable place-shaping") to understand the concepts and practice in place branding by looking at the role of communities (or in our case, residents) in terms of the roles played in place branding. This, in turn, helps us to understand how to actively engage and empower local residents in the process of branding their place via their own values and meanings.

\section{From mainstream place branding to inclusive place-based approaches}

Place branding semantics have been largely dominated by economic discourses and globalization pressures favouring inter-place competitions (Morgan et al. 2011). Consequently, the majority of place branding practices tend to be 
market-driven and entrepreneurial centred (Ashworth 2011), often disregarding residents' voices and needs (Colomb 2011). Such practices of promoting commodification and competitiveness of place as a unique selling point are problematic. There are voices within academia and society that challenge such discourses. These dissents can be classified into three types, as below:

First, criticisms that confront the dominant views of place branding as a commercial-interest activity, arguing that any disregard towards the complexity of history, knowledge, culture, and practices can have negative consequences on the local social fabric (see Evans 2003; Lichrou et al. 2008; Johansson 2012). For example, place-branding can be seen as a neoliberal instrument of urban governance which ignores communities' voices and needs and only serves the interest of local elites and external audiences. Place branding is also accused of applying 'quick-fix solutions' in various situations without considering the specific geographical, socio-political and ecological contexts, and consequently increasing sameness of places instead of contributing to the awareness about specific sociocultural and historical assets and individual identity (Lucarelli and Giovanardi 2014).

Second, citizens-through several grassroot movements-have been raising their voice against neoliberal place branding practices. For instance, a counter-branding movement emerged in Amsterdam when residents, feeling disconnected from the city marketing strategies, created 'I AMsterdamned' (borrowed from a 1988 horror film of similar name) against the official slogan "I AMsterdam" (Braun et al. 2013). Another interesting example is the case of Hamburg where city branding and marketing efforts mainly catered for high-income residents and tourists whilst disregarding the majority of citizens' view of the city's image. This resulted in public demonstrations and a manifesto against place gentrification, called 'Not In Our Name!' which criticized the strategies for turning the city into a brand (NION 2010). Dissident voices like these are a reflection of the main downsides and negative outcomes of those contemporary place branding exercises that fail to include and engage key stakeholders, such as residents, in planning the future of their places (see Aitken and Campelo 2011; Kavaratzis and Kalandides 2015). It also reveals the extent of misconceptions existing amongst city officials and marketers about place branding as a mere publicity stunt (Ashworth and Kavaratzis 2010).

Third, stemming from the above critiques, a stakeholderoriented body of the literature has recently emerged (see Braun et al. 2013, Dominguez Garcia et al. 2013; Kavaratzis 2012, Zenker and Erfgen 2014). It asserts that rather than a managerial or entrepreneurial approach towards place, branding should be seen as a collective process that seeks to translate the meanings of place for its various stakeholders (Kavaratzis 2012). In this sense, it argues particularly for the role of residents as the principal group of stakeholders in place branding, who play a key role in supporting an inclusive brand co-creation and development, assuring its success and long-term sustainability (see Aitken and Campelo 2011; Kavaratzis and Kalandides 2015; Klijn et al. 2012). Braun et al. (2013) identify three inclusive non-exclusionary and sometimes overlapping roles that residents can play in place branding which are of particular interest:

- ... as citizens, with political power of legitimating place brands;

- ... as an integrated part of a place brand via creating and representing the core values and meanings of place;

- ... as ambassadors, who advocate for their place and grant credibility to the place brand.

Building on the stakeholder-oriented literature, Lichrou et al. (2017:4), in an edited volume, refer to inclusive place branding as "the foundations for a more responsible development of the place branding discipline". Such forms of place branding should ideally "(a) go beyond economic interests and goals; (b) focus on the residents; (c) integrate the voices of many stakeholders through participatory methods; (d) 'listen' to the non-powerful” (Lichrou et al. 2017:4). These authors acknowledge that such approaches are yet to be found in practice and that the concept has not been clearly delineated either, but rather exists as a point of reference for more critical perspectives towards place branding. There is, therefore, a need for new contributions that explore alternative themes and approaches via novel methodologies to assist the development of a sound understanding of what inclusive place branding may mean.

\section{Inclusive place branding: a framework to enhance residents' participation via sustainable place-shaping}

Critical perspectives in place branding have favoured more participatory and inclusive practices that allow local actors to define their place meanings (see Kavaratzis 2012; Lichrou et al. 2017). However, concepts such as participation and inclusion are very complex and relative, and may be interpreted by different actors on the spectrum in different ways. As a result, there is always a possibility that well-intended actions may prove counter-productive, and result in sometimes excluding residents from deliberations (Cassinger and Thelander 2017). With a few exceptions, such as Zenker and Erfgen (2014) and Donner et al. (2016), place branding studies do not generally exemplify or provide comprehensive frameworks on how to make use of local experiential knowledge, and how to successfully involve, engage and empower local actors, particularly 


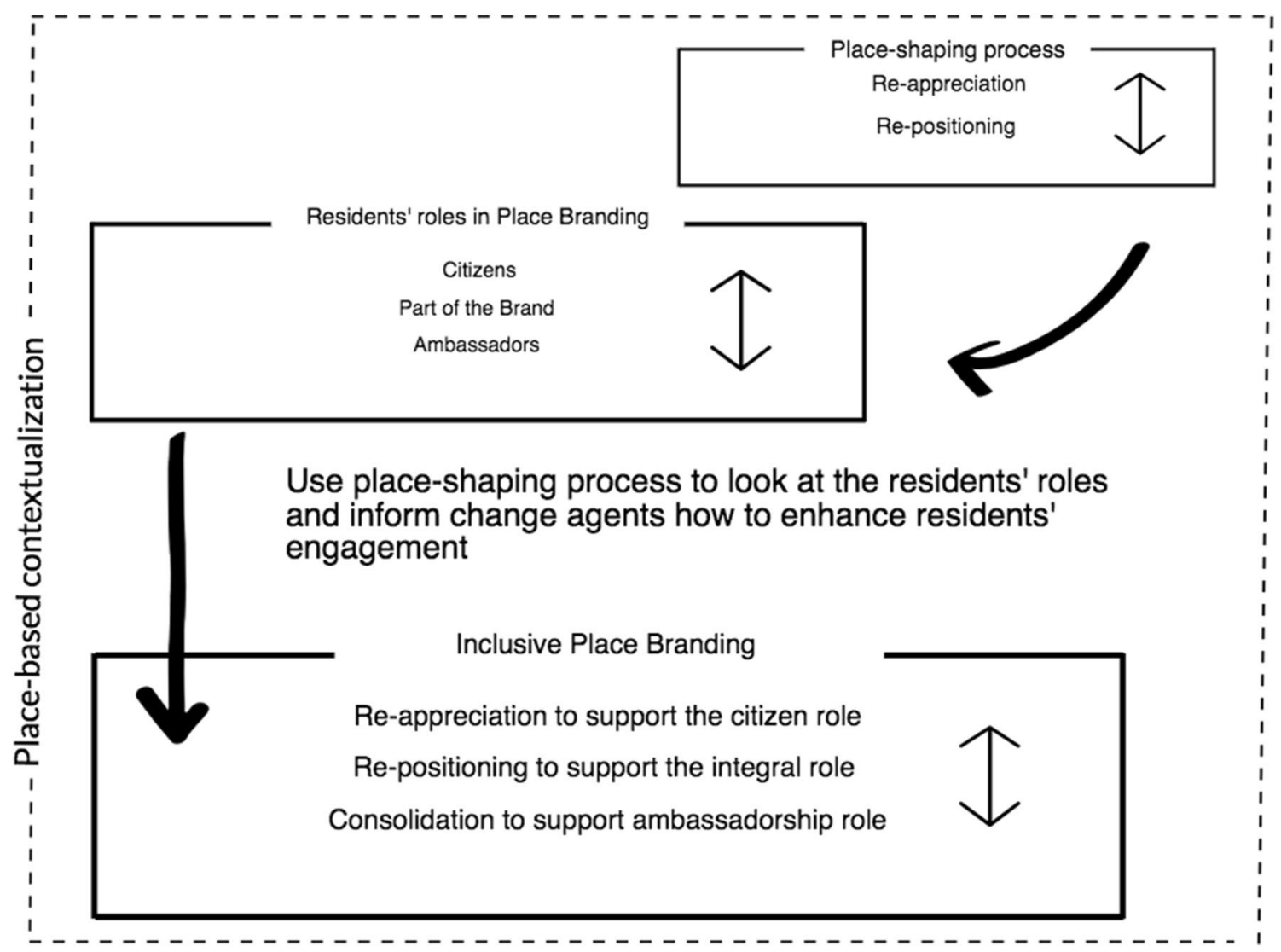

Fig. 1 A framework for inclusive place branding

the under-privileged stakeholders in the branding process (Vanolo 2017). The strategic use of local experiential knowledge involving and empowering local communities in the branding process may contribute to endogenous developments such as identity building and social learning. Hence, there is a need to understand the complexity of place meanings, values and sense of place, capitalizing on the understandings and experiences of residents, and to articulate the knowledge into an inclusive place branding conceptualisation.

Aiming to fill this gap and contribute to the advancement of concept and practice in participatory and inclusive place branding, we propose a new framework that links critical views in place branding with those of place-shaping. Integrating place-shaping with the roles that residents play in place branding can help with actively engaging and empowering residents in the processes of branding their place, applying their own values and meanings. This may subsequently help an inclusive branding that stimulates inhabitants' collective agency towards place-based development and cohesion.

We suggest four non-linear and inter-connected phases: (a) place-based contextualization; (b) re-appreciation: supporting the role residents as citizens; (c) re-positioning: residents as integral to place branding; and, (d) consolidation: ambassadorship of place.

Figure 1 outlines the proposed framework for inclusive place branding, which combines place branding concepts with the interdisciplinary notion of place-shaping. We borrow the re-appreciation and re-positioning pathways for sustainable place-shaping as defined by Horlings and Roep (2015) and apply them in the branding context to explore how these processes can be used to stimulate participants' engagement and roles in brand co-creation. Each of the four processes is explained as follows.

\section{Place-based contextualization}

For our analysis, we consider place not just as a geographical administrative area, but also as an outcome of multiple, dynamic and constantly changing social interactions (Massey 1994). This understanding clearly challenges the "one size fits all" strategies generally applied in mainstream branding, which ignore how place is constructed (Warnaby 2011). Indeed, any given place can have different sets of perceptions, conceptions and meanings according to various contexts. Consequently, any strategies that disregard these complexities are condemned to fail. On the contrary, 
a place-based approach respects the complexities and fluid meanings of place by engaging its people to collaboratively drive long-term and sustainable changes from the ground up via sets of tools for its contextualization. Place-based views also allow the communities to take charge of their future, to speak for themselves, and to build social capital and connections from within to create the best measures for their long-term development (Anheier and Leat 2006). A place-based approach should, therefore, be the foundation for any project of place branding that aims to be inclusive and socially responsible.

\section{Re-appreciation: supporting the role of residents as citizens}

Re-appreciation can be defined as the process of sense-making of a place and its qualities by its own residents. Arguably, residents have the power to legitimize, or not, place meanings and brands and, thus, play their role as citizens (Braun et al. 2013). The challenge, however, remains that communities can only play their roles as legitimators if sufficient means are made available to empower participatory decision-making over how a brand should be thought of and developed to represent place. Having a shared role in joint decision-making can enhance residents' civic participation, as well as their role as legitimators, which will flow much more naturally as the place brand is co-designed from the bottom-up. Residents, however, need motivation, encouragement and trust to attach values and meanings, e.g. through place-embedded narratives, to convey their tacit knowledge and senses of place. This motivation and trust may be facilitated and stimulated via the re-appreciation of their place. That is, residents may be guided by a researcher and or practitioner through a re-appreciation process, which can assist them to become more aware of the place qualities, assets and strengths, as well as expose points to be improved, or offer future visions for the place (Dominguez Garcia et al. 2013; Horlings 2015). Re-appreciation is essential to stimulate the residents' role as citizens by opening up a space for them to reflect, shape and re-shape the social and cultural meanings, values and notions that they attach to their place. Re-appreciation is, therefore, a valuable exercise to co-create a collective account of place, which, in turn, serves as a significant input for the development of an inclusive place brand.

\section{Re-positioning: residents as integral to place branding}

Re-positioning is a transformative process, anchored in the re-appreciation of place, that facilitates residents in changing their place-based relationships from passive to active sense-making, and consequently (re)shaping their place meanings. Re-positioning thus stimulates residents' capacity to appropriate themselves in relation to the dominant perspective of place in favour of a new one, collaboratively initiated through bottom-up deliberation. This strengthens residents' capacity by enabling them to develop novel ways of articulating their place meanings, values and perceptions to decision-makers who are, generally, charged with delivery of top-down place branding strategies. Re-positioning in central for shifting unsustainable discourses and considering residents' core values and meanings (e.g. community stories and narratives about their place) in the branding co-creation. This, in turn, facilitates the residents' role as an integral element of the branding efforts (Braun et al. 2013), leading to a more genuine and grounded place identity.

\section{Consolidation: ambassadorship of place}

Residents are more likely to become place advocates and play an ambassadorial role when they are proactively involved in the place branding effort (Braun et al. 2013; Chen and Dwyer 2017). This reflects a direct relationship between place engagement and ambassadorship. We regard ambassadors as an assemblage of internal stakeholders with strong connections to their place, assembled either formally or informally, with the primary aim of appreciating their place socially, culturally, environmentally and economically by means of its external promotion. Both the processes of re-appreciation and re-positioning intend to inspire active participation and agency of residents in the transformation, co-creation and dissemination of their place meanings and place representation as well as their hypothetical place brand, and consequently, fulfil their roles as ambassadors. Thus, consolidation reinforces these two previous processes as well as stimulating a collective reflexive process via a discussion of the core values and meanings that represent the place for the group. Subsequently, it encourages acceptance and shared responsibility as well as ownership over this co-created place representation (e.g. in the form of visual narratives) which may, in turn, enhance residents' sense of belonging and renew their pride for the place and, consequently, boost their desire to act as ambassadors. Ambassadorship of place is vital for place branding, since it helps convey an authentic and trustworthy message for sharing, engagement and celebration of local values.

\section{Methodology-collaborative visual narratives}

The interconnected but non-linear framework developed above paves the way for application of an inclusive place branding approach. For this purpose, we used 'visual documentary making' as a collaborative tool with a participatory action research element linking the researcher with the 
community. Visual methods are useful for their heuristic and collaborative potential (Lapenta 2011), facilitating participants' engagement and promoting dynamic and perpetual dialogue between the researcher and the community (O'Brien et al. 2014). Such methods can be expressed under different terms such as collaborative video, community video, or participatory video (Mitchell and Lange 2011). The participatory component of visual documentary methods helps to include, energize and actively empower people in shaping and conveying their place meanings and hypothetical brand (Pink 2001). Due to this particular emphasis on supporting community voices and activism, a participatory action research approach seemed appropriate for this research. This approach allows for meaningful collaboration for social change and participants' empowerment, whilst developing knowledge both for participants and researchers by building upon reflective practices. Nevertheless, it is a time-consuming process, demands commitment by all involved and exposes power dynamics within the community; thus, the researcher needs to be aware of whose voices are (not) being heard (McTaggart 1994; Torfing et al. 2019). Torfing et al. (2019) have particularly warned against the barriers as well as risks of participatory selectiveness which tend to favour those with time, energy and knowledge to influence on joint decisions.

Based on the above, we carefully adopted a co-creation approach for the recording, processing, production and sharing of visual narratives in the form of a documentary. The objective of research was twofold. First, it supported the skill building of the researcher, for which a local socio-cultural NGO Binaural-Nodar was contacted to provide technical assistance as well as to support the documentary co-creation. The selection of this NGO was based on their expertise and experience in creative audio-visual technologies for the documentation, facilitation and promotion of both tangible and intangible features in rural areas. All technical amenities (equipment, filming, editing) were operationalized with Binaural-Nodar and guided by the overall research objectives. Second, the filming and research had to take place 'with and for' the participants rather than just 'on' the participants. For this purpose, the lead researcher took residence in the area to be closer to the community. This allowed engagement with the territory, to offer a positive contribution to tangible and long-term processes and outcomes which go well beyond the research project. This approach allowed the researchers to give something in return (the video documentary) to the community and, therefore, value participants' time, commitments and efforts.

\section{Carvalhal de Vermilhas, Portugal: a case study}

Carvalhal de Vermilhas, a small village in Vouzela county (Fig. 2) with a population of 200 inhabitants, was selected for two main reasons. First, the village is suffering from incessant depopulation and ageing issues (INE 2016). This illustrates the archetype of many small towns and villages in rural Portugal. Hence, successful research work in such a deprived area could facilitate the ability to apply the methods in other similar places. Second, part of the village is denominated as a Natural Park and offers nature trails for hiking. In the wake of the rural shrinkage, local government has been considering tourism as a possible avenue to salvage the rural economy. For this purpose, it developed a branding strategy for the county "Vouzela-the heart of the centre" to raise the area's profile both nationally and internationally. These administrative assumptions, however, remain top-down, and fail to consider local communities' reservations and concerns. After several informal conversations with Carvalhal de Vermilhas' inhabitants, it became clear that the Natural Park designation and boundaries were devised and enforced against the community's will.

To proceed with the research and production of the documentary, participants were recruited via purposive sampling through leaflet distribution in public spaces (e.g. a coffee shop, a food shop, a local church, a folklore association), through word-of-mouth invitation in the village streets, and also an open invite published both in the local newspaper and on Facebook. In a period of 15 days, we succeeded in recruiting 11 participants (see Table 1). All participants were requested to sign an informed consent form that explained the purpose of the project to ensure that there were no reservations about their part on filming and sharing their stories.

\section{Data collection}

The data collection was organized in four main stages (Fig. 3) briefly explained below, and further described with empirical relevance in the results section. It follows the four-phase framework to facilitate its operationalization and analysis. Data collection techniques were influenced by the visual anthropology literature (see Pink 2001; Mitchell and Lange 2011), and based on the appreciative inquiry principles with a focus on the best of the strengths that places and communities have on offer (Barrett and Fry 2005). Therefore, an environment of cooperation, valorisation, inclusiveness and equality rather than competition was promoted in all the project stages. In addition, we collected qualitative and unstructured data (e.g. through dining with participants; walks around the village with a camera to capture places mentioned in the video-taped interviews; and folklore performance ${ }^{1}$ observations). These activities, when intertwined with more structured ways of data

\footnotetext{
${ }^{1}$ Some of the recruited participants belong to a folklore group that aims to preserve village heritage of traditional songs and dances. .
} 


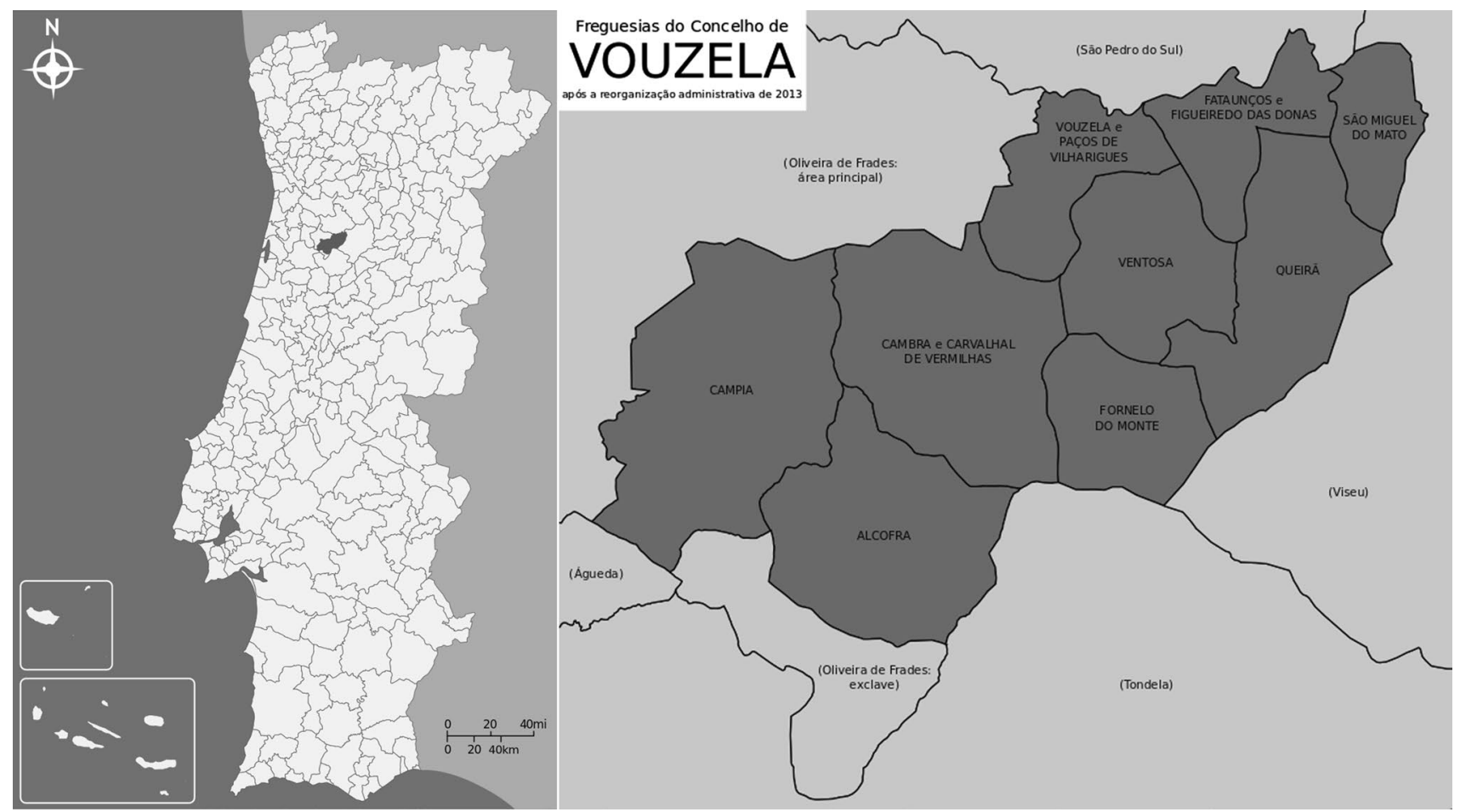

Fig. 2 Vouzela County (Portugal) map Source: Vouzela County web portal

Table 1 Participants' demographics

\begin{tabular}{llllll}
\hline Gender & Place of Birth & Age & Education & Profession & $\begin{array}{l}\text { Participant } \\
\text { number and } \\
\text { FG }\end{array}$ \\
\hline Male & Barreiro & 28 & Higher Education & Entrepreneur & 1 FG: B \\
Female & Barreiro & 27 & Higher Education & Marketeer & 2 FG: A \\
Female & C. Vermilhas & 47 & Higher Education & Teacher & 3 FG: A \\
Male & C. Vermilhas & 57 & Higher Education & Legal Technician & 4 FG: B \\
Male & C. Vermilhas & 41 & Higher Education & Commercial & 5 FG: A \\
Female & C. Vermilhas & 72 & Primary school & Farmer & 6 FG: B \\
Male & C. Vermilhas & 80 & Primary school & Farmer & 7 FG: A \\
Male & C. Vermilhas & 77 & Secondary School & R/Bank officer & 8 FG: A \\
Female & C. Vermilhas & 69 & Primary School & R/Beekeeper & 9 FG: B \\
Male & C. Vermilhas & 80 & Primary School & Farmer & 10 FG: B \\
Female & C. Vermilhas & 71 & Primary School & Housewife & 11 FG: B
\end{tabular}

C. Vermilhas, Carvalhal de Vermilhas; R/, retired; FG, focus group collection, provided insights into the community life. These also played an important role in enhancing the relationship of trust between the researcher and the community. All the collected data were analysed via thematic analysis.

Stage 1 comprised the lead researcher's integration and contextualization both in Carvalhal de Vermilhas and in Binaural-Nodar. The process took approximately 1 month, and involved visual observations, informal conversations, visits to the points of interest, and document analysis (e.g. local demographics). Training in visuals skills such as documentary making was also part of this stage and was carried out at Binaural-Nodar.

Stage 2 was initiated by informal conversations with the recruited group to clarify their needs and motivations. This 
Fig. 3 Data collection stages

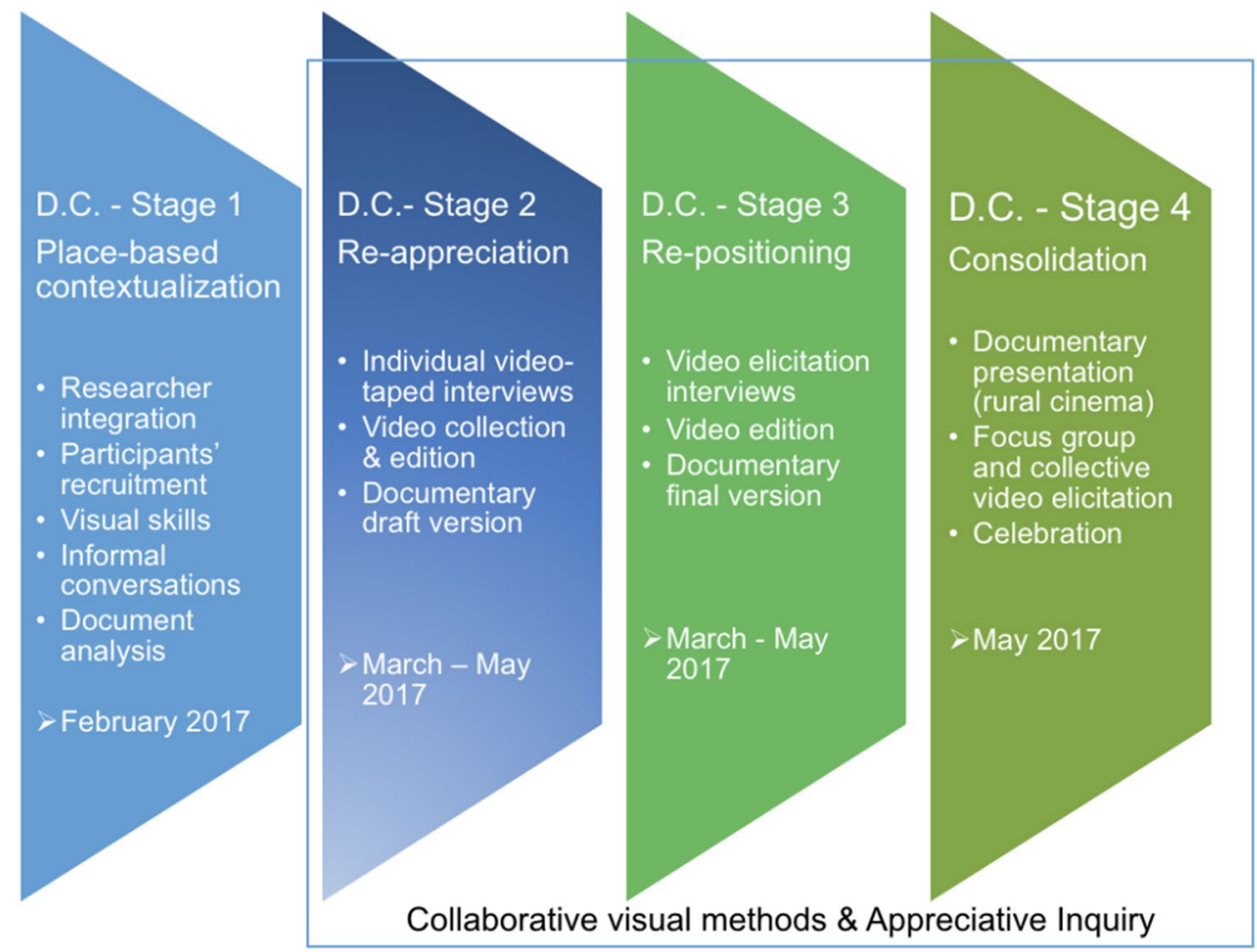

was followed by eleven individual video-taped interviews which comprised general demographic questions to start the conversation and the main research questions based on appreciative inquiry. Video interviews took between 30 and $50 \mathrm{~min}$ each. Only the responses to the main questions were included in the documentary. The next part of stage 2 included several technical activities: (1) narratives identification; (2) reduction of the individual video-taped interviews into short videos of 2-3 min; (3) new videos/images collection that match the narratives (e.g. built heritage); and (4) short-videos editing and elaboration of the documentary's first draft.

Stage 3 involved a second set of interviews with the same participants, building on the Stage 2 work, i.e. new interview questions guided and based on the short-videos (video elicitation). The interviews took approximately $1 \mathrm{~h}$, and had three parts each presented in two stages before and after participants watched the short videos. The responses assisted the second round of editing of the short videos, and consequently of the documentary's final version.

Stage 4 comprised activities such as a rural cinema, video elicitation/focus group and celebration. The first activity, the rural cinema, was used to present the final documentary to all participants who were gathered for the first time to watch each other's visual narratives. Following this, a collective video elicitation and focus groups were organized to discuss the documentary and its co-creation process. For this purpose, two groups, designated as A and B, were organized and moderated by the researcher. This stage concluded with a 'celebration moment', in the form of a group meal.

\section{Results: application and analysis of the conceptual framework}

This section illustrates how the interconnected non-linear phases suggested in our conceptual framework (Sect. "Inclusive place branding: a framework to enhance residents' participation via sustainable place-shaping") were applied in the research. It also presents and analyses the main results of its application, as well as the follow-up actions.

\section{Place-based contextualization in practice}

A place-based approach brings a set of tools for the contextualization of place and its people and, therefore, is required for any inclusive place branding project. Living close to the community and applying several research techniques described in stage 1 (Sect. "Data collection") helped with a better insight into the community characteristics, motivations and needs. This subsequently informed our sampling, recruitment process and project design. The process, aligned with the training in visual skills, proved to be essential to tailor the research methodology to the local context and to the profile of the recruited participants. For example, due to the village demographics, more than half of the recruited participants were over 65 years old, with different levels of 
education (Table 1). Therefore, the questions were adapted and the original idea of allowing the participants to make their own videos of the village was reformulated. The group comprised three different generations from the same villages besides two new comers. This complexity was reflected in the identified narratives which represent the past, present and future of the village as well as in two types of place attachment, as identified by Lewicka (2011) in terms of traditional and active attachment, resulting in rich and multifaceted narratives of place. However, the focus of this paper remains on the main outputs of the process of an inclusive form of place branding co-creation rather than the identity building.

\section{Re-appreciation in practice}

Re-appreciation can allow residents to become more aware of their place qualities and open up the space for them to reflect, shape and re-shape its social and cultural meanings. As such it encourages them to act as citizens of their place and deliberate over how a hypothetical brand should be cocreated. The process of re-appreciation was operationalized via three main questions (stage 2): (1) what makes your village special? (2) What story/experience best reflects your appreciation of your village? And, (3) what would you like to tell outsiders about your village? Answering these questions increased participants' reflexivity over what they value about their place and helped them to make sense and verbalize what place means for them. This, in turn, enhanced their agency to deliberate and give voice to their ideas of what it is important to express about their place. The narratives that emerged from this process reflected participants' views and values of place. For example, key themes identified tend to value the beautiful nature of the place "(...) the landscape is magnificent $(\ldots)^{2}$ ", its culture and tradition “( $\left.\ldots\right)$ religious traditions are intertwined with folklore songs $(\ldots)^{3}$ ", its built heritage " $(\ldots)$ we have the cromlech that we call Lapa da Meruje $(\ldots)^{4 \prime}$, its people and a strong sense of community "(...) I like the people very much, because they are very humble, very welcoming $(\ldots)^{5}$ ", and the importance of the place for their subsistence "(...) I like working in the fields $(\ldots)^{6 ”}$. According to participants' opinions, these are the main key themes that represent their sense of place and identity.

\footnotetext{
2 Participant 3 (Table 1).

${ }^{3}$ Participant 4 (Table 1).

${ }^{4}$ Participant 9 (Table 1).

5 Participant 3 (Table 1).

${ }^{6}$ Participant 6 (Table 1).
}

\section{Re-positioning in practice}

Re-positioning reinforces residents' capacity to position themselves in relation to the dominant perspective of place, including how this can be represented in a hypothetical inclusive place branding strategy. The process of re-positioning was applied via a second set of interviews based on eleven short videos that resulted from the re-appreciation exercise (stage 2). The interviews aimed to continue and strengthen the reflexive process initiated in the re-appreciation, and consequently reinforce their agency in the direction of making change and of transforming their place meanings and representations. For this purpose, reflective questions about participants' experiences of village life with emphasis on attachment to place and sense of place were posed. More specifically, questions related to what were the participants' main concerns and issues of living in Carvalhal de Vermilhas were encouraged to support the transition from re-appreciation to re-positioning. Through such questions, the main issue identified by the majority of the respondents was the general incapacity of the area to hold younger inhabitants, either due to lack of job opportunities or modern infrastructure, which had led to an ageing population and increased depopulation: “(...) some years ago no one would tell that it would be possible to have such an ageing population in Carvalhal de Vermilhas, that we would be in a problematic situation of just having five children in the entire village (...) with technological advancement and modernization we have contact with other places and cities ... and we also want the best for our children, so we can't stay in the village and work in agriculture... we can't... agriculture today is a subsistence activity... we produce potatoes and we have to eat them because we can't sell them $(. . .)^{7}$ ". In addition to stimulating transformation of the dominant perspective of place, by allowing participants to voice their place views and concerns, we also aimed to include and engage them in the co-creation of a novel way to articulate these views and deliberations.

Hence, a number of questions related to the video co-creation were presented. Participants were asked, for example: what did they like most and least about the videos? What would they change? The responses assisted with the second round of editing the short videos, and consequently the documentary. This ensured that the main key themes of the final documentary represented participants' sense of place and identity and, therefore, that they were happy with it and indeed proud of what they had co-created.

\footnotetext{
$\overline{7 \text { Participant }} 3$ (Table 1).
} 


\section{Consolidation in practice}

Consolidation aimed to reinforce the previous processes of re-appreciation and re-positioning as well as to stimulate a collective reflexive process. That is, for the first time, participants were able to discuss together, as a group, their place relations and how to alter these relations to (re)shape their place representations and, therefore, potentially act as informal ambassadors for their place and indeed, hypothetical brand. The consolidation process was operationalized via the final version of the co-created documentary, which served as an elicitation tool to initiate deliberations where participants were divided into two small focus groups. For example, participants were asked to comment on the documentary title, and identify the sense or senses of place that emerged from the collective visual narratives.

Both groups also discussed the documentary and its cocreation as well as each step of the project and its processes (re-appreciation, re-positioning and the last one, consolidation). The co-creation aspect of the project was appreciated by the participants and resulted in the new knowledge and increased awareness about the residents' sense(s) of place and identities:

"this project allowed us to exchange thoughts and learn to value different stories".-Group B

The co-creation process also resulted in participants' increased self-esteem as well as in senses of empowerment and achievement. According to the participants' reflections, they did not expect to have the capacity to transform their place relations and be able to co-create in a new way (visual narratives) to articulate their own meanings, values, stories and representations of their place, as they did in this project:

"the project surprised us, because despite our group being composed of many old people we did a great job (video documentary)."-Group A

"I never thought we could do it, neither that I would see such a beautiful thing here in Carvalhal de Vermilhas".-Group B

Regarding the project processes, the main reflections suggested that having a space for civic participation and decision-making was important for participants; a space where they were able to reflect and transform their place relations as well as re-shape their meanings of place. Following the conceptual framework allowed the mobilising and engaging of the participants in discussions and decisions about what Carvalhal de Vermilhas meant to them both individually and collectively:

"one of the most important parts of the project was the time to reflect in a group upon our village and what the village means for all of us.”-Group A
Applying the framework processes with the group also resulted in (re)connecting the place with the participants:

"actually, we learnt from different testimonies that the way we see the village is different (...) however, irrespective of the person, age or profession, all of us cherish a great love for this land."-Group B

Their potential role as ambassadors was also discussed. Participants were asked to propose as to with whom and why should they share the visual narratives from the cocreated documentary, to represent their place values, meanings, senses and identity. Both groups were unanimous in identifying local authorities as the first choice, followed by:

"policy makers, who need to see the richness of the interior."-Group B

"friends and family, with people who used to live here, but also with the urban dwellers."-Group B

The residents also stressed the importance of reaching out to the central government for the overall development of rural Portugal. Participants particularly believed that the co-created documentary may be a valuable way of informing authorities about rural assets.

Participants were also asked what they thought would be necessary for them to become formal ambassadors. Both groups agreed that they were not keen on becoming formal ambassadors, since they already considered themselves ambassadors in an informal sense, as advocates for their place. Participants, however, recognized that this project reinforced their collective agency by helping them to create a group capable of taking decisions and actions to steer their own future:

"this project is just the beginning."-Group B

"watching [and listening to] our community stories gave me greater motivation to promote and preserve our heritage."-Group A

\section{Project follow-up}

After the completion of the field work, the lead researcher moved out of the community. However, communication channels and good relations were maintained with all participants. 3 months later Carvalhal de Vermilhas residents and Binaural-Nodar contacted the researchers to say that they were planning a public viewing of the co-created video documentary. The participants' reflections and dialogues prompted by the re-appreciation, re-positioning and consolidation processes encouraged them to transform their thoughts into action, reconsider their roles as informal ambassadors, and conduct further outreach activities. 


\section{Discussion}

Literature in place branding has argued for more socially responsible and inclusive practices to involve, engage and empower local actors and citizens, particularly the underprivileged (Lichrou et al. 2017; Vanolo 2017). This research has developed and empirically applied a new conceptual framework on inclusive place branding whilst addressing the two research questions as listed in Sect. "Introduction" and discussed in Sect. "Results" above. To summarise: on one hand, place-shaping processes presented in four interrelated phases of our conceptual framework: place-based contextualization, re-appreciation, re-positioning and consolidation, aligned with an action research approach, particularly the collaborative visual methods, supported and stimulated a group of residents in the creation of a collective agency to co-decide which narratives, values and identities should be articulated to promote and create a more inclusive representation of their place of residence in a (hypothetical) branding exercise. On the other hand, the role of collaborative visual narratives (the co-created documentary) was to provide the necessary tools to co-create this collective vision and message of what these residents, if asked, would like to see represented in a more inclusive place brand.

We refer to the brand as hypothetical, because this was an exploratory study with time and resource restrictions, to develop an actual place brand for the village. The collaborative visual methodology applied in this research demanded considerable time and emotional commitment from the participants as well as the researchers. Answering several personal and emotional questions in front of camera requires high levels of mutual trust. The NGO Binaural Nodar had an important role in facilitating and mediating a relationship of trust and assisting with the video resourcing and editing. However, collaboration and co-creation is a challenging task, particularly in time-constrained projects, which resulted in some conflicts as well. The main challenge was about the documentary co-creation, where the researchers and the NGO had to negotiate and compromise.

Indeed, the co-creation of a participatory and inclusive brand that respects the social fabric of places (Lichrou et al. 2008) is a complex process that demands long-term negotiation and cooperation. However, unlike quick-fix market driven solutions only focused on mere economic benefits (Colomb 2011), this research exercise, even with its own limitations, helped to create awareness of the local assets, and allowed for building identity, capacity and transformative agency as significant first steps towards sustainability of place as well as the brand (Aitken and Campelo 2011).

The outputs support the argument of Lichrou et al.'s (2017) that place branding exercises, whenever developed with communities in a socially responsible manner, may leverage community development, and reinforce citizen's identity and identification with their place, as well as provide a social force to reduce social exclusion. It also corroborates Kavaratzis' (2012) argument that place branding cannot be seen as a top-down and narrowly economic and neoliberal undertaking, but a collective process that seeks to translate the meanings of place for its various stakeholders, particularly the residents. Again, due to limited resources, this study could only gather views of a small group of residents, who demonstrated interest and willingness to take part in research. This brings up the issue of representation and inclusiveness. In other words, this documentary is not necessarily representative, or inclusive of the views of, the whole Carvalhal de Vermilhas community. It is rather a collaborative interpretation of the researchers as initiators, the NGO as a mediator, and each of the individual participants of the project. Therefore, it is very likely that other points of view and issues of concern about the area are not represented in the short documentary. This corroborates Quick and Bryson's (2016) argument that participatory processes are rarely as inclusive as they might aim to be as well as Torfing et al. (2019) assertion on the selectiveness aspects in participatory and co-creation projects. In fact, the same is true of co-creation. Participants (especially the elderly) did not have the time, or express a need, to learn video production skills. The video editing was co-created by the researchers and the NGO.

Even the work of this scale requires extensive human and financial resources to explore the benefits and challenges of a holistic and participatory approach in place-branding, with a particular focus on creative and collaborative visual techniques. Although, it is difficult to recognize the full potential of co-creation approaches in practice, following Torfing et al. (2019), we believe that there is much more to gain than to lose from it:

First, this research substantiates co-created documentaries as a useful tool for empowering communities to express their voices and be heard. It allowed participants to transform their exploratory dialogues and narratives into collective agency (as in the video public viewing), and therefore, fulfil their roles as informal ambassadors of the place (Braun et al. 2013). Second, it also initiated a momentum that may lead to social change by transforming the co-created documentaries into a policy tool that could inform local and national policy makers (the main target of the documentary's public viewing) over the future of their village, as well as its branding strategies. This supports Hollings's (2015) argument that the dialogues which stimulate people's senses of place are a valuable source of information for policymakers in the processes of participative deliberations. However, if we aim to transform these initial conversations and narratives into 
an actual practice of inclusive place branding, more work and support is needed. Local authorities need to be more open to the participants' voices, and initiate collaborations that deal both with the issues and challenges of living in remote rural areas as reflected in the visual narratives. This exercise would be more than a process of identity building, a first step in brand co-creation, and address significant and urgent questions such as what sustainable paths for place development may a collaborative and grounded place branding strategy bring?

\section{Conclusion: place-shaping research practices as co-creating transformative agency}

In this paper, we have detailed a conceptually and methodologically rigorous approach to developing effective participatory and inclusive place-shaping, and indeed, a hypothetical place brand. These have, using a case study of Carvalhal de Vermilhas as a rural Portuguese village, demonstrated the value and challenges of co-creating place-shaping processes using, a new conceptual framework. This requires a considerable time commitment of the researchers involved and those researched; and it engages residents' involvements in defining for themselves the rich ways in which their places can be articulated and branded. In these ways, the approach creates opportunities more broadly for transformative agency to be propagated around inclusive and collective place constructions. More specifically, this involved four interrelated phases of work: place-based contextualisation, re-appreciation, re-positioning and consolidation. The approach used and integrated visual methods as a key means through which these processes can be applied and the results demonstrated important longer term impacts on the residents' reflections and articulations of their places.

This demonstrated an active and continuous process of place-shaping, and indeed, through their very reflections, a new collective narrative and visualisation of place. It opened up the pathways of: residents as citizens; residents as an integrated part of the place brand; and residents as longer term place 'ambassadors' (Braun et al. 2013). And, it co-created place stories via a full appreciation of their own place-based values, stories and meanings. Indeed, it stimulated a more embedded and rooted appreciation of the problems and opportunities of the place. It is an empowered set of visions and articulations, which could be used to promote the place to visitors and potentially new and younger residents and workers. Mixing visual methods with a variety of other data collection methods encouraged collective agency and capacity in exploring, articulating, and voicing their joint narratives, and for these to be seen as a new starting point for the residents to take forward into the future, which is an inherently central aspect of sustainable rural development.

Indeed, future research could explore how generic rural development issues such as depopulation and ageing, the major concerns expressed by the research participants, may be addressed through such empowering approaches towards place-shaping and branding. How can younger age-groups participate in these approaches? New collaborative discussions, with a larger and more diverse group of stakeholders, including the local authorities, could discuss how a new collective narrative and visualisation of place may contribute to reduce the depopulation issue that severely affects the village. Apart from attracting tourists as well as new residents, how can this co-creation process help in the development of new sustainable practices for the territory? How can the collective transformative agency, stimulated by the present conceptual framework be transferred towards different but complementary activities such as sustainable agri-food processes?

Acknowledgements The authors are very grateful to Dr. Dirk Roep, Wageningen University, Netherlands, Dr. Lummina Horlings, University of Groningen, Netherlands, Matthew Quinn, Cardiff University, United Kingdom, and Professor Robin Attfield, Cardiff University, United Kingdom, for their comments on an earlier version of the manuscript.

Funding This project has received funding from the European Union's Horizon 2020 research and 703 innovation programme under the Marie Skłodowska-Curie Grant agreement no. 674962.

Open Access This article is distributed under the terms of the Creative Commons Attribution 4.0 International License (http://creativecommons .org/licenses/by/4.0/), which permits unrestricted use, distribution, and reproduction in any medium, provided you give appropriate credit to the original author(s) and the source, provide a link to the Creative Commons license, and indicate if changes were made.

\section{References}

Aitken R, Campelo A (2011) The four Rs of place branding. J Market Manag 27:9-10. https://doi.org/10.1080/0267257X.2011.560718

Allen C, Crookes L (2009) Fables of the reconstruction: a phenomenology of 'place shaping' in the North of England. Town Plan Rev 80(4-5):455-480

Anheier K, Leat D (2006) Creative philanthropy: towards a new philanthropy for the 21 st century. Routledge, London

Ashworth GJ (2011) Marketing and organisational development in e-SMEs: understanding survival and sustainability in growthoriented and comfort-zone pure-play enterprises in the fashion retail industry. Int Entrepreneurship Manag J 23:25-38. https:// doi.org/10.1007/s11365-011-0171-6

Ashworth GJ, Kavaratzis M (eds) (2010) Towards effective place brand management: branding european cities and regions. Edward Elgar, Cheltenham, Northampton

Barrett J, Fry E (2005) Appreciative inquiry: a positive approach to building cooperative capacity. Taos Institute, Chagrin Falls 
Boisen M, Terlouw K, Groote P, Couwenberg O (2017) Reframing place promotion, place marketing, and place branding-moving beyond conceptual confusion. Cites. https://doi.org/10.1016/j.citie s.2017.08.021

Braun E, Kavaratzis M, Zenker S (2013) My city—my brand: the role of residents in place branding. J Place Manag Dev 2013:18-28

Cassinger C, Thelander A (2017) Spaces of identity in the city: embracing the contradictions. In: Karavatzis M, Giovanardi M, Lichrou, M (eds) Inclusive place branding. Routledge, London, pp 70-81

Chen N, Dwyer L (2017) Residents' place satisfaction and place attachment on destination brand-building behaviors: conceptual and empirical differentiation. J Travel Res. https://doi. org/10.1177/0047287517729760

Colomb C (2011) Staging the new Berlin: place marketing and the politics of reinvention post-1989. Routledge, London

Dominguez Garcia M, Horlings LG, Swagemakers P, Fernández SX (2013) Place branding and endogenous rural development. Departure points for developing an inner brand for the River Minho estuary. Place Branding Public Diplomacy 9:124-140

Donner M, Horlings LG, Fort F, Vellema S (2016) Place branding, embeddedness and endogenous rural development: four european cases. In: Place branding and public diplomacy, pp 1-20. https:// doi.org/10.1057/s41254-016-0049-z

Evans G (2003) Hard-branding the cultural city—from Prado to Prada. Int J Urban Reg Res 27(2):417-440

Gibson-Graham JK (2008) Diverse economies: performative practices for 'other worlds'. Hum Geogr 32:613-632

Horlings LG (2015) Values in place; A value-oriented approach toward sustainable place-shaping. Reg Stud Reg Sci 2(1):257-274. https ://doi.org/10.1080/21681376.2015.1014062

Horlings LG (2016) Connecting people to place: sustainable placeshaping practices as transformative power. Curr Opin Env Sustain 20:32-40. https://doi.org/10.1016/j.cosust.2016.05.003

Horlings LG (2017) The role of artists and researchers in sustainable place-shaping. In: Asikainen S, Brites C, Plebańczyk K, Mijatović LR, Soini K (eds) Culture in sustainability: towards a transdisciplinary approach (pp 130-143). (SoPhi; vol 139). Jyväskylä: University of Jyväskylä, SoPhi

Horlings LG, Roep D (2015) Projectproposal Marie Curie ITN, Wageningen: WUR, unpublished

INE (2016) Instituto Nacional de Estatistica, Portugal

Johansson M (2012) Place branding and the imaginary: the politics of re-imagining a Garden City. Urban Stud 49(16):3611-3626

Kavaratzis M (2012) From "necessary evil" to necessity: stakeholders involvement in place branding. J Place Manag Dev 5(1):7-19. https://doi.org/10.1108/17538331211209013

Kavaratzis M, Kalandides A (2015) Rethinking the place brand: the interactive formation of place brands and the role of participatory place branding. Env Plan A 47(6):1368-1382. https://doi. org/10.1177/0308518X15594918

Klijn EH, Eshuis J, Braun E (2012) The influence of stakeholder involvement on the effectiveness of place branding. Public Manag Rev 14(4):499-519
Lapenta F (2011) Some theoretical and methodological views on photo-elicitation. SAGE Handb Vis Res Methods 11:201-213. https://doi.org/10.4135/9781446268278.n1

Lewicka M (2011) On the varieties of people's relationships with places: hummon's typology revisited. Env Behav 43:676-709

Lichrou M, Lisa O’Malley L, Patterson M (2008) Place-product or place narrative(s)? Perspectives in the marketing of tourism destinations. J Strateg Market 16(1):27-39. https://doi. org/10.1080/09652540701794429

Lichrou M, Kavaratzis M, Giovanardi M (2017) Introduction. In: Karavatzis M, Giovanardi M, Lichrou M (eds) Inclusive place branding: critical perspectives on theory and practice. Routledge, London, pp 12-22

Lucarelli A, Giovanardi M (2014) The political nature of brand governance: a discourse analysis approach to a regional brand building process. J Public Affairs 16(1):27-39

Massey D (1994) A global sense of place. Marx Today 1994:24-29

McTaggart R (1994) Participatory action research: issues in theory and practice. Educ Action Res 2(3):313-337

Mitchell C, Lange N (2011) Community-based participatory video and social action in rural South Africa (9). SAGE Handb Vis Res Methods. https://doi.org/10.4135/9781446268278.n9

Morgan N, Pritchard A, Pride R (2011) Tourism places, brands, and reputation management. In: Morgan N, Pritchard A, Pride R (eds) Destination brands: managing place reputation. ButterworthHeinemann, Oxford, pp 3-19

NION (2010) Not in our name! Jamming the gentrification machine: a manifesto. City 14(3):323-325

O'Brien V, Dhuffar M, Griffiths M (2014) Collaborative visual ethnography: practical issues in cross-cultural research. SAGE Res Methods Cases. https://doi.org/10.4135/978144627305014533924

Pink S (2001) Doing ethnography: images, media and representation in research. Sage, London, p 196 (ISBN 0-7619-6154)

Quick S, Bryson J (2016) Theories of public participation. In: Handbook of theories of governance

Shucksmith M (2010) Disintegrated rural development? Neo-endogenous rural development, planning and place-shaping in diffused power contexts. Soc Rural 50(1):1-14

Torfing J, Sørensen E, Røiseland A (2019) Transforming the public sector into an arena for co-creation: barriers, drivers, benefits, and ways forward. Adm Soc 51(5):795-825. https://doi. org/10.1177/0095399716680057

Vanolo A (2017) City Branding, the ghostly politics of representation in globalising cities. Routledge, London

Warnaby G (2011) What About the place in place marketing? In: Paper Presented at the Academy of Marketing 2011 Conference, Liverpool, UK

Zenker S, Erfgen C (2014) Let them do the work: a participatory place branding approach. J Place Manag Dev 7(3):225-234. https://doi. org/10.1108/JPMD-06-2013-0016

Publisher's Note Springer Nature remains neutral with regard to jurisdictional claims in published maps and institutional affiliations. 